\title{
Pesan Dakwah dalam Karya Sastra
}

\author{
Nina Herlina ${ }^{1 *}$, Dang Eif Saiful Amin $1^{1}, \&$ Rohmanur Aziz ${ }^{2}$ \\ ${ }^{1}$ Jurusan Pengembangan Masyarakat Islam, Fakultas Dakwah dan Komunikasi, UIN Sunan \\ Gunung Djati, Bandung \\ 2Jurusan Pengembangan Masyarakat Islam, Fakultas Dakwah dan Komunikasi, UIN Sunan \\ Gunung Djati, Bandung \\ *Email:Herlinanina706@gmail.com
}

\begin{abstract}
ABSTRAK
Tulisan ini bertujuan untuk mengetahui bagaimana struktur makro pesan dakwah dalam novel Athirah, Superstruktur pesan dakwah dalam novel Athirah, dan struktur mikro pesan dakwah dalam novel Athirah karya Alberthiene Endah. Metode penelitian menggunakan metode pendekatan analisis wacana bersifat kualitatif, Dalam analisis wacana model Teun A. Van Dijk ini meneliti tentang mencari struktur makro teks tentang tematik. sedangkan superstruktur dibahas dalam skematik, dan struktur mikro teks yaitu dari segi semantik, sintaksis, stilistik dan retoris. Hasil penelitian menunjukan yaitu secara struktur makro dalam novel ini disusun dalam tema kesabaran, dan ketangguhan seorang perempuan bernama Athirah dalam menghadapi cobaan hidup. Secara superstruktur Alberthiene Endah membuat novel ini dengan alur maju mundur, ada alur yang menceritakan masa lampau, namun tetap mudah dimengerti oleh pembaca. Sedangkan secara struktur mikro Alberthiene Endah menggunakan bahasa yang cukup luas dan bahasa kiasan atau perumpamaan. Bentuk kalimat yang digunakan kebanyakan menggunakan bentuk kalimat aktif.
\end{abstract}

Kata Kunci : Pesan dakwah; Karya sastra; Novel ; Analisis Wacana Teun A. Van Djik

\section{ABSTRACT}

This paper aims to determine how the macro-structure of the novel Athirah propaganda message, superstructure message Athirah propaganda in the novel, and the microstructure of propaganda messages in the novel Athirah Endah Albertbiene work. The research method using the method of discourse analysis approach is qualitative, in discourse analysis Teun A. $V$ an Dijk. models is researching on the search for the macro-structure of thematic text. while the superstructure is discussed in the schematic, and the microstructure of the text that is in terms of semantic, syntactic, stylistic and rhetorical. The results showed that in the structure of 
the macro in this novel are arranged in the theme of patience, and a woman named Athirah toughness in the face of life's trials. In the superstructure Alberthiene Endah make this novel with the flow back and forth, there are grooves that tell of the past, but still easily understood by the reader. While the microstructure Albertbiene Endah using language that is quite extensive and figurative language or imagery. Tenses used mostly using active voice form.

Keywords : Propaganda messages; Literature work; novel; Discourse Analysis Teun A. Van Djik

\section{PENDAHULUAN}

Kegiatan dakwah dalam perkembangannya, menjadikan media tulisan sebagai salah satu media untuk menyampaikan pesan dakwah. Sehingga kegiatan dakwah tidak hanya terbatas pada memberikan atau menerima ceramah di depan mimbar saja namun juga lebih variatif. Tulisan adalah media atau alat yang cukup efektif untuk dijadikan sebagai media dakwah.

Manusia dengan segala aktivitas dan kesibukannya akan sangat dimudahkan dengan adanya tulisan yang memiliki muatan-muatan dakwah. memberikan pengaruh yang relatif besar, dalam kemajuan dan perkembangan dakwah Islam, sehingga dapat mudah diterima oleh berbagai kalangan. Media dakwah tentunya adalah media yang bisa digunakan untuk menjadi ruang dalam menyampaikan pesan-pesan dakwah Islam.

Dari jejak sejarahnya, sebenarnya media ini telah dikenal dari zaman dahulu, tercermin pada kitab-kitab karya para ulama, termasuk karya terbesar bagi umat Islam yaitu Al-Qur'an. Manusia mengharapkan suatu inovasi baru untuk menyampaikan pesan dakwah yang tidak hanya bisa didengarkan dan bersifat sekilas, salah satunya yaitu novel atau karya tulisan sastra yang menggunakan bahasa-bahasa yang menarik, tidak membosankan dan bahasa yang indah sehingga mampu menjadi media yang berkelas dalam menyampaikan pesanpesan dakwah.

Manusia dengan segala aktivitas dan kesibukannya akan sangat dimudahkan dengan adanya tulisan yang memiliki muatan-muatan dakwah. memberikan pengaruh yang relatif besar, dalam kemajuan dan perkembangan dakwah Islam, sehingga dapat mudah diterima oleh berbagai kalangan. Media dakwah tentunya adalah media yang bisa digunakan untuk menjadi ruang dalam menyampaikan pesan-pesan dakwah Islam.

Dari jejak sejarahnya, sebenarnya media ini telah dikenal dari zaman dahulu, tercermin pada kitab-kitab karya para ulama, termasuk karya terbesar bagi umat Islam yaitu Al-Qur'an. Manusia mengharapkan suatu inovasi baru untuk menyampaikan pesan dakwah yang tidak hanya bisa didengarkan dan bersifat sekilas, salah satunya yaitu novel atau karya tulisan sastra yang menggunakan bahasa-bahasa yang menarik, tidak membosankan dan bahasa 
yang indah sehingga mampu menjadi media yang berkelas dalam menyampaikan pesan-pesan dakwah.

Berdakwah menggunakan karya sastra merupakan salah satu bentuk tulisan yang dapat digunakan sebagai alat (media) untuk berdakwah. Novel adalah bentuk karya sastra yang paling diminati di dunia. Dengan gaya komunikasi yang relatif mudah menyentuh masyarakat. Novel juga termasuk dalam genre fiksi, fiksi itu adalah salah satu yang termasuk genre sastra.

Adapun yang dimaksud dengan novel adalah sastra karangan prosa yang panjang, mengandung rangkaian cerita kehidupan seseorang dengan orang disekelilingnya dengan menonjolkan watak dan sifat setiap pelaku (Meity, et.,al, 2011: 62).

Novel merupakan salahsatu terobosan untuk mengajak manusia lewat tulisan-tulisan sastra, yang memiliki makna yang indah namun terdapat pesan yang mampu dijadikan sebagai tuntunan. Hal tersebut perlu diperhatikan dalam penyampaian pesan yang bermuatan dakwah atau suatu materi yang akan disampaikan, baik disampaikan dengan tulisan, lisan ataupun dalam tindakan.

Seperti halnya dalam novel atau dalam tulisan-tulisan sastra, yang mengandung ajakan untuk berbuat sabar, menjadi manusia yang kuat dan menjadi wanita yang berbakti kepada suami, bagaimana mengajarkan sifatsifat yang baik pada anaknya, merupakan contoh yang pas untuk dijadikan sebagai pesan dakwah yang disampaikan dan dijabarkan dalam bentuk tulisan sastra atau novel. Novel yang biasanya hanya berisi dengan ceritacerita fiksi, sekarang dalam perkembangannya novel diubah menjadi media untuk menyampaikan nilai-nilai kebaikan dalam berdakwah.

Penyampaian pesan dakwah melalui karya tulis dari Alberthiene Endah yang memiliki beragam keunikan yaitu novel yang terinspirasi kisah nyata yakni menceritakan sosok wanita inspiratif, dari salah satu orang berpengaruh di negara ini yakni Jusuf Kalla.

Novel Athirah karya Alberthiene Endah ini adalah novel yang berfokus pada penyampaian biografi sosok Athirah bersama keluarganya. Novel ini merupakan jenis novel biografi yaitu jenis yang menceritakan perjalanan hidup seseorang. Diterbitkan oleh Nooura books, pada tahun 2013, dengan memiliki jumlah bab sebanyak 14 bab, terdiri dari 404 halaman,

Novel ini menarik untuk diteliti sebab merupakan novel yang terispirasi dari kisah nyata, yaitu cerita salah satu tokoh nasional di Indonesia, selain itu novel tersebut juga bercerita tentang tangguhnya sosok perempuan bernama Athirah yang merupakan ibu dari Jusuf kalla, kemudian novel ini dirangkai dalam bahasa yang menarik, dan makna yang dalam. Medium tulisan tersebut mampu menyampaikan pesan-pesan inspirasi dan memiliki pesan keislaman yang bisa diaplikasikan dalam kehidupan sehari-hari, yang 
disampaikan kepada mad'u nya, sehingga melalui tulisan-tulisan tersebutlah, semua pembaca mampu mendapatkan pesan-pesan moril yang disampaikan oleh penulis.

Pada penelitian ini, peneliti berfokus pada beberapa bab cerita pada Novel Athirah, peneliti hanya mengambil empat judul karena memiliki pesan dakwah yang lebih dominan dibandingkan dengan judul cerita yang lain dari novel tersebut. Adapun cerita yang diteliti, yaitu diantaranya cerita yang berjudul: Perempuan dari Rabim Kesabaran, Engkau Mengalah Bukan Kalah, Perlawanan, Ikblas dan syukur, untuk meneliti pesan-pesan dakwah pada bagian-bagian bab yang memiliki muatan klasifikasi pesan dakwah diantaranya pesan aqidah, pesan dakwah Syariah ibadah, muamalah dan juga Akhlak.

Seperti pada penelitian Skripsi sebelumnya yang berjudul Analisis Wacana Buku Cinta di Rumah Hasan Al-Banna Karangan Muhammad Lili Nur Aulia. Penelitian ini berkaitan dengan penggunaan media cetak atau dalam bentuk tulisan. Adapun penelitiannya menggunakan metode analisis wacana, model Teun van A. Djik. Yang berhubungan dengan Akidah, hukum ibadah, dan hukum muamalah dan kewajiban-kewajiban lainnya.

Penelitian Pesan Dakwah dalam karya sastra pada novel Athirab ini memiliki kesamaan penelitian dengan beberapa skripsi sebelumnya, seperti sama-sama melakukan penelitian terhadap karya tulis, dengan menggunakan analisis yang sama, yaitu analisis wacana Teun Van A.Djik. Adapun yang menjadi perbedaannya yaitu terletak pada jenis karya tulis yang di telitinya.

Dari latar belakang masalah tersebut dapat dirumuskan beberapa masalah dengan fokus penelitian: Bagaimana struktur makro pesan dakwah dalam karya sastra pada novel Athirah karya Alberthiene Endah? Bagaimana superstruktur pesan dakwah dalam karya sastra pada novel Athirah karya Alberthiene Endah? Bagaimana struktur mikro pesan dakwah dalam karya sastra pada novel Athirah karya Alberthiene Endah?

Dalam penelitian ini peneliti menggunakan metode analisis wacana model Teun A. Van Djik, metode analisis wacana sifatnya kulitatif, sehingga mengandalkan penafsiran peneliti terhadap teks. Metode analisis wacana bertujuan untuk memfokuskan pada pesan tersembunyi. Bagaimana pesan-pesan tersebut tersampaikan dalam sebuah teks, hal tersebut bisa diketahui oleh analisis wacana. Pemilihan menggunakan metode analisis wacana dari Teun A. Van Djik ini karena yang menjadi objek dari penelitiannya adalah hal seputar tentang tema, skema dan pesan-pesan yang terkandung dalam novel tersebut, tentunya yang memiliki unsur dakwah didalamnya. Sehingga melalui pendekatan dan menggunakan metode analisis wacana ini agar mampu menjelaskan sebagai suatu fenomena mengenai persoalan komunikasi Penyiaran Islam dalam media cetak. 


\section{LANDASAN TEORITIS}

Teori yang digunakan dalam landasan penelitian ini adalah teori yang berkaitan dengan pesan dakwah menggunakan media tulisan, yaitu melalui karya sastra. Adapun secara bahasa Sedangkan menurut bahasa mendefinisikan bahwa dakwah berasal dari bahasa arab yaitu $d a^{\prime} a$, yad'u, da'wan, du'a, yang diartikan sebagai mengajak atau menyeru, memanggil, seruan, permohonan dari permintaan (Munir dan Ilahi 2006: 17)

Dakwah di definisikan sebagai ajakan, seruan, himbauan atau usaha untuk mengajak umat manusia kepada kebahagiaan yang hakiki, kebahagiaan yang sebenarnya, dengan menyebarkan nilai-nilai Islam kepada manusia, baik menggunakan media tulisan, perkataan ataupun perbuatan, untuk mencapai kebahagiaan di dunia dan juga di akhirat. Pada intinya, dakwah merupakan prilaku muslim dalam menjalankan Islam sebagai agama Islam (Tajiri, 2015: 17).

Dalam Al-Qur'an kedudukan dakwah sangat penting dalam kehidupan manusia, hendaknya ada orang yang memiliki pengetahuan untuk menebarkan nilai-nilai Islam, baik bersifat individu atuapun golongan baik itu laki-laki atau perempuan. Dakwah adalah suatu proses mengajak, menyeru, dan membimbing umat manusia untuk berbuat baik dan mengikuti dan mengikuti petujuk Allah dan Rasul-Nya (Saerozi, 2013:11).

Dalam suatu keberhasilan kegiatan dakwah tidak akan terlepas dari rukun atau unsur-unsur yang harus ada dalam proses dakwah, yang satu sama lain saling berkaitan. Unsur-unsur dakwah adalah komponen-komponen yang terdapat dalam setiap kegiatan dakwah (Munir, et.,al, 2009:21).

Pertama, Däi Subjek dalam melakukan kegiatan dakwah, bisa secara individual ataupun golongan, dalam melakukan kegiatan dakwah. Da'i memiliki posisi yang sangat penting atau yang sangat sentral dalam berdakwah, sehingga sangat penting seorang da'i memiliki citra dan juga image yang baik, dalam masyarakat. Kedua, Sasaran dakwah atau disebut juga dengan sebutan mad'u tidak lepas dari kultur kehidupan yang melingkupinya yang harus dipertimbangkan dalam pelaksanaan dakwah. Situasi teologis, kultural dan struktural mad'u (masyarakat) dalam dakwah Islam bahkan selalu memunculkan dinamika dalam kegiatan dakwah

Ketiga, pesan dakwah Diantara kategori pesan yang terdapat dalam AlQur'an itu seputar akidah, ibadah, muamalah, akhlak dan juga sejarah. Al-Qur'an merupakan sumber pesan dari kegiatan dakwah, sebagai pedoman hidup bagi umat muslim. Pesan dakwah secara umum meliputi: Pertama, ajaran yang berupa ushuliyah (pilar dan kerangka dasar atau pokok utama) sebagaimana diisyaratkan dalam Q.S.Al-Baqarah, 2: 177. Kedua, karakteristik pesan dakwah yang diistilahkan Al-Quran sebagai syariah, washiyah Allah, Shirath mustaqim, Din Qayim, dan Milah Ibrahim.(Sambas, 2019:90-91). 
Keempat, Pada kata awalnya kata metode ini berasal dari kata yunani methodos yang memiliki arti mengikuti, jalan atau cara. Metode dakwah atau yang disebut juga dengan Uslub Al-da'wah adalah metode atau cara yang digunakan oleh da'i dalam menyampaikan pesan dakwah. Metode dakwah juga sangat penting peranannya dalam menyampaikan pesan dakwah (Aripudin, 2011:8) .

Kelima, media dakwah atau wasilah da'wah Wasilah da'wah atau media dakwah adalah sarana yang dapat digunakan dalam berlangsungnya kegiatan dakwah, Berdakwah adalah bagian dari proses komunikasi. Dakwah merupakan suatu proses memberikan informasi atau pesan kepada orang lain dengan menggunakan bahasa sebagai medianya. (Indrawati 2013: 221).

Materi atau pesan dakwah Dalam kegiatan menyeru atau mengajak kebaikan dilakukan dengan berbagai macam diantaranya yaitu dengan dakwah bil-kitabah, yang didalamnya mengandung pesan-pesan Islam yang bisa dijadikan sebagai suatu pedoman, untuk mencapai keselamatan dunia dan akhirat.

Pesan dalam ajaran Islam adalah perintah, nasehat, permintaan, amanah, yang harus disampaikan kepada orang lain. Sedangkan pesan dakwah adalah semua pernyataan yang bersumber dari Al-qur'an dan as-sunnah baik secara tertulis maupun dalam bentuk lainnya (Amin, 2009:11).

Pesan ialah segala sesuatu yang dikomunikasikan oleh pengirim kepada penerima pesan, dan pesan dalam komunikasi ini adalah seperangkat bentuk simbol baik itu berupa simbol verbal atauapun non verbal yang mewakili pesan yang akan disampaikan (Ilahi, 2010:97).

Pesan dakwah adalah masalah isi pesan dakwah atau materi yang disampaikan da'i kepada mad'u atau orang yang menerima pesan. Dalam penyampaian pesan dakwah seharusnya sumber Al-Quran dan Al-Hadits baik lisan ataupun tulisan dengan menyampaikan pesan yang bertanggung jawab. Sedangkan dalam ilmu komunikasi pesan dijelaskan dengan teknik komunikasi secara informatif, persuasif dan instruktif (Tasmara: 1997:43).

Menurut Ramdani, dakwah melalui tulisan ialah prosees menyampaikan dakwah yang gagasan atau materi dakwahnya berupa huruf-huruf yang diolah menjadi kata dan digabung menjadi kalimat erta disusun paragraf hingga menjadi topik tertentu (Ramdani, 2018: 47-48)

Menurut Samsul Munir Amin mengklasifikasikan dakwah bil qalam dalam pendekatan atau metode dakwah ialah cara-cara yang digunakan dalam menyampaikan dakwah agar pesan dakwah mudah diterima oleh penerima pesan (mad'u). Amin menyebutkan tiga pendekatan dakwah antara lain: dakwah bil lisan, dakwah bil qalam, dan dakwah bil hal (Amin, 2009: 13). 
Menurut Enjang dan Aliyudin (2009-60) dakwah bil-kitabah ialah proses penyebarluasan pesan-pesan keisliman yang berupa bahasa tulisan seperti buku, novel, majalah, pamflet dan lain sebagainya.

Menurut Abu Al-fatah Al-Bayanuni menyebutkan jika dakwah bil-kitabah menjadi bagian taksonomi yang berkaitan dengan tabligh yaitu komunikasi risalah islamiyah dengan menggunakan komunnikasi, diantaranya: 1). Komunikasi lisan (khitabah al-thasiriyah dan khitabah al-diniyah). 2). Komunikasi tulisan (kitabah) dan 3). Irsyad (Bimbingan dan penyuluhan). (Sukayat, 2015: 13).

Sastra ialah karya tulis yang jika dibandingkan dengan karya tulis yang lain, memiliki berbagai ciri keunggulan seperti keorsinilan, keartistikan, serta keindahan dalam isi dan ungkapannya ( Sugono 2003: 159)

Karya sastra terbagi kedalam dua macam yaitu fiksi dan nonfiksi, jinis karya sastrea fiksi adalah puisi, drama, dan prosa. Sedangkan contoh karya sastra nonfiksi adalah biografi, autobiografi, kritik sastra dan esai.

Novel adalah sebuah bentuk karya modern. Yang menyajikan suatu makna yang ekspresif, kisah yang didalamnya bersumber dari berbagai hal yang fiktif tapi tidak jarang juga memang bersumber dari hal-hal yang nyata. Karya saatra khususnya novel mengandung nilai-nnilai tertentu berupa kebaikan yang dapat mempengaruhi jiwa kehidupan seseorang (indrawati 2013: 217).

Novel adalah sastra karangan prosa yang panjang, mengandung rangkaian cerita kehidupan seseorang dengan orang disekelilingnya dengan menonjolkan watak dan sifat setiap pelaku (Meity, et.,al, 2011: 62).

"Kata novel berasal dari kata Novella, yang dalam bahasa Jerman istilah novel yaitu novelle, dan novel dalam bahasa Inggris, dan inilah yang kemudian masuk ke Indonesia. Secara harfiah novella berarti sebuah barang baru yang kecil yang kemudian diartikan sebagai cerita yang pendek dalam bentuk prosa" (Nurgiantoro, 2010: 9).

Nurujuman, Husnan "Simbolisasi Islam sebagai identitas tidak hanya mewujud pada praktik kehidupan pengamalan Islam sehari-hari, tapi juga hadir dalam produk-produk budaya seperti lagu, film dan novel". (Nurujaman, 2018: 65)

Maka novel adalah bentuk karya sastra berupa cerita tentang kehidupan seseorang dilingkungannya, serta cerita itu dikemas didalam sebuah karya tulis, yang pelaku-pelakunya beradegan dari sebuah adegan ke adegan lain, dari satu tempat ke tempat yang lai. Serta bisa dikatakan sebuah novel jika didalamnya terdapat dan mampu memunculkan nilai-nilai budaya, sosial, moral, dan pendidikan.

\section{HASIL DAN PEMBAHASAN}


Penelitian ini dilaukan pada sebuah karya sastra bentuk novel yang berjudul Athirah karya Alberthiene Endah, atau yang memiliki nama lengkap Rr. Alberthiene Endah Kusumawardhani Sutoyo, lebih dikenal sebagai Alberthiene Endah, adalah seorang penulis dan jurnalis Indonesia. Ia terkenal akan karyakarya biografinya tentang tokoh-tokoh dunia hiburan tanah air, seperti Krisdayanti dan Chrisye. Ia disebut sebagai "biografer" yang paling banyak diminta di Indonesia.

Diantara karya-karya nya yaitu: pertama, seribu satu KD, panggung hidup dengan tokoh Raam Punjabi, Chrisye: sebuah memoar musikal, Ani yudhoyono: kepak sayap putri prajurit, Merry Riana-Mimpi sejuta dolar, Joko Widodomenyentuh Jakarta, dan Athirah, sebagai novel yang terinspirasi dari kisah Jusuf Kalla dan ibunda Athirah.

Novel Athirah ini adalah novel yang menggambarkan kisah seorang perempuan tangguh bernama Athirah yang tinggal di kota Bone Makasar. Dalam novel Athirah tersebut menceritakan tentang Sosok gambaran seorang ibu yang penuh dengan cinta kasih, menampilkan sosok istri mulia yang tak pernah sedikitpun kehilangan hormat kepada suaminya, beliau adalah ibu dari Jusuf kalla, yaitu Athirah. Berbagai gejolak rumah tangga yang harus di hadapinya, bersama anak laki-laki tertua yaitu Jusuf. Di umur sangat mudanya tugas itu harus dia jalankan yaitu di umur 16 tahun. Hanya dengan Jusuf Emma Athirah menentramkan keadaan rumah bahwa semua baik-baik saja ada bapak atau tak ada bapak. Emma Athirah sangat tangguh, keadaan mengharuskan beliau meredam emosi hati melanjutkan hidup dengan separuh hati yang hilang. Selama 40 tahun, Jusuf menjadi sahabat terdekat sekaligus tempat bercerita ibunya yang membesarkan semua anaknya. Semua kearifan itu diserap dan diterapkannya ketika mengembangkan bisnis NV Hadji Kalla dan melebarkannya di kawasan Indonesia timur.

Hasil penelitian ini menemukan struktur makro pesan dakwah dalam karya sastra pada novel Athirah, superstruktur pesan dakwah pada nnovel Athirah, dan struktur mikro pada novel Athirah karya Alberthiene Endah.

\section{Struktur Makro Pesan Dakwah Karya Sastra dalam Novel Athirah}

Dalam struktur makro ini menganalisis tema dari setiap cerita, yaitu diantaranya yaitu cerita berjudul: perempuan dari rabim kesabaran, engkan mengalah bukan kalah, perlawanan, ikblas dan syukur. Kata tema sering dibandingkan dengan kata topik dalam sebuah tulisan utuh untuk mengungkapkan sesuatu yang informasi atau gambaran yang penting untuk disampaikan oleh komunikator (Sobur, 2015:75).

Pertama, perempuan dari rahim kesabaran yaitu Cerita ini menceritakan tentang sosok perempuan yang tangguh dalam menghadapi cobaan dalam kehidupannya. Emma Athirah adalah sososk wanita yang lahir dari rahim 
kesabaran. Hingga sebuah masalah dalam rumah tangganyaa, mulai terjadinya kegelisahan yang terlihat dari keluarganya yang tentram dan baik-baik saja.

Kedua, Cerita engkau mengalah, bukan kalah adalah salah satu cerita yang terdapat dalam novel Athirah, cerita ini menggambarkan bagaimana kehidupan berat, dan kesedihan seorang anak yang terlibat dalam kisah poligami, menyaksikan salah satu dari orang yang sangat di hormati harus menahan perih, dan pedih, terutama kepedihan yang dirasakan Emma. Pada bagian dalam cerita ini juga menceritakan bagaimana kehidupan keluarga Emma Athirah dan anakanaknya perlahan-lahan berubah, termasuk pada Bapak yang akan datang berkunjung ke rumah Emma Athirah pada waktu menjelang Isya, dan akan kembali menuju isteri keduanya.

Ketiga, Cerita ini menceritakan tentang pergulatan kehidupan anak-anak beserta Emma untuk bekerja keras dalam menghadapi perubahan pada suasana rumah, berpura-pura tak sedih. Lalu mulai membayangkan kembali bagaimana kerukunan keluarga pada masa lalu. Kehidupan yang harmonis dan tentram.perjuanagan anak-anak dalam penghiburan untuk membela hati seorang Emma yang terluka.

Keempat, Cerita ikhlas dan syukur adalah salah satu cerita yang dimuat dalam novel Athirah, cerita ini menggambarkan tentang mengambil pelajaran, dan hikmah dari apapun yang tejadi pada kehidupan yang akan adatang, sikap sabar dan ikhlas seorang Emma Athirah dalam menghadapi apapun yang terjadi, menjadikan sebuah pelajaran untuk kehidupan anak-anaknya. Dan ibu adalah pembelajaran terbaik bagi anak-anaknya.

Tabel. Struktur makro pesan Dakwah

\begin{tabular}{|c|c|c|}
\hline No & $\begin{array}{l}\text { Struktur Makro } \\
\text { Pesan Dakwah }\end{array}$ & $\begin{array}{c}\text { Kalimat Yang Mengandung Struktur } \\
\text { Makro Pesan Dakwah }\end{array}$ \\
\hline 1 & Sabar & $\begin{array}{l}\text { "jika kau tanya apa yang menyakitkan } \\
\text { dari kenyataan ayah menikah lagi, aku tak } \\
\text { akan menjawab berlama-lama } \\
\text { mendengarnyapun sudah sakit. Apalagi } \\
\text { melewati masa sesuadabnya. Aku tabu, } \\
\text { ketika pernikahan itu telah resmi, maka } \\
\text { rumabku di jalan Andalas akan merintis } \\
\text { perjuangan baru. Buka lagi perjuangan gigih } \\
\text { orang tua membesarkan usaba seperti yang } \\
\text { kulihat sejak kecil. Tapi untuk perjuangan } \\
\text { untuk bersabar dan tawakal bukan hanya } \\
\text { Emma, juga kami anak-anaknya. Perasaan } \\
\text { luka, bapak menikah lagi tak banya } \\
\text { menggesek satu hari, barangkali akan } \\
\text { beribu-ribu hari setelah pernikahan itu }\end{array}$ \\
\hline
\end{tabular}


terjadi, barangkali sepanjang hidup kami"

Sumber: hasil penelitian

Tabel.1 menjelaskan mengenai pesan dakwah secara struktur makro atau secara global dari topik atau tema. Adapun yang dimaksud dengan Pesan dalam ajaran Islam adalah perintah, nasehat, permintaan, amanah, yang harus disampaikan kepada orang lain. Sedangkan pesan dakwah adalah semua pernyataan yang bersumber dari Al-qur'an dan as-sunnah baik secara tertulis maupun dalam bentuk lainnya (Amin, 2009: 11).

Hasil dari penelitian pada struktur makro pesan dakwah dalam karya sastra, pada novel Athirah pada bab judul perempuan dari rahim kesabaran, Engkau mengalah, bukan kalah, perlawanan, ikhlas dan syukur, secara keseluruhan atau tema yang mendominasinya yaitu tentang tema mengenai sikap sabar dalam menghadapi ujian tercemin dari beberapa pesan dakwah yang terdapat dalam setiap judul cerita yakni anjuran sabar, Tabah dalam menghadapi kesedihan, kuat tak mudah menyerah, bersyukur dalam keikhlasan. Jadi secara global pada keempat judul cerita yang dipilih oleh peneliti mendominasi tema kesabaran seorang sosok perempuan bernama Athirah dalam menghadapi ujian dan cobaan dalam hidup.

\section{Superstruktur Pesan Dakwah Karya Sastra dalam Novel Athirah}

Pada penelitian bagian ini membahas tentang bagiamana skematika penulis dalam menyajikan tulisannya, dari pada bagian ini juga hal yang di teliti adalah menjelaskan dan membedakan judul, lead cerita dan isi cerita. Maka peneliti menjelaskannya per cerita, karena peneliti hanya mengambil beberapa cerita

Pertama, Judul cerita : Perempuan dari Rahim Kesabaran, Summary (Lead), judul ini menggambarkan apa yang ingin dibicarakan dalam teks. Dalam awal cerita ini menceritakan terlebih dahulu bagaimana kerinduan seorang Jusuf Kalla kepada Emma Athirah setelah beliau wafat. Dalam judul ini menceritakan, bagaimana seorang Emma Athirah itu terlahir dari rahim kesabaran dari seorang ibu bernama Kerra yang memiliki pernikahan yang sulit, dan menjadi seorang isteri ke empat dari pernikahannya dengan Mohammad seorang terpandang kampung Bukaka. Kalimat dalam bagian isi cerita ini memberikan penekanann terhadap bagaimana bersikap sabar dalam apapun yang sedang terjadi, karena apapun yang sedang terjadi dalam kehidupan manusia itu adalah sepenuhnya atas keinginan Allah.

Dijelaskan juga di lead lainnya bahwa percakapan tentang hal itu adalah awal dari perjalanan batin yang tak pernah dibayangkan akan datang, diawali mulai kegelisahan Emma, dan Nurani yang membawa kabar jika Bapak mencintai orang lain. Dalam cerita ini menceritakan bagaimana ketakutan seiorang anak yang belum dewasa yang mendapat kabar jika Bapaknya mencintai 
wanita lain. Dijelaskan kemudian bagaimana Jusuf Kalla beserta saudarasaudaranya menghormati Haji Kalla yang merupakan orang terpandang di seantero Makasar, dan sekarang Bapak mencintai orang lain, dan orang lain mulai bergunjing tentang hal itu dan hal ini merupakan pukulan. Dijelaskam juga bahwa pada tahun itu adalah tahun yang sangat sulit, karena kehamilahan Emma Athirah kian membesar.

Kedua, Judul cerita : Engkau mengalah bukan kalah, Summary (Lead), Cerita ini didahului dengan pernyataan pengalaman terberat seorang anak yang memiliki masalah keluaga poligami, yang harus menyaksikan salah satu dari orang tua mengalami luka, semenjak sosok Bapak yang menikah lagi. Meskipun Emma Athirah terus berusaha menciptakan suasana yang wajar. pada kalimat lainnya ketika Emma Athirah mendapatkan surat dengan isi yang tajam yang menyatakan jika Emma telah mengganggu rumah tangga Bapak, sehingga Emma Athirah mulai merasa bahwa apakah dia kalah dalam hal ini. Meskipun cobaan datang pada kehidupan Emma Athirah dan keluarganya, Emma Athirah memiliki anak-anak yang sangat mencintainya, bahwa Emma tidak kalah, Emma hanya mengalah.

Dalam bagian ini diceritakan bagaimana perasaan Emma Athirah dan anak-anaknya setelah mendapatkan tragedi Bapak menikah lagi, banyak hal yang berubah dan meninggalkan luka terutama pada Emma Athirah dan anakanaknya. Namun meskipun Emma athirah dan anak-anaknya sangat terpukul dan sedih atas kejadian tersebut, semuanya selalu berusaha untuk tetap sabar, dan terlihat baik-baik saja, melakukan aktivitas dan kesibukan seperti biasanya.

Ketiga, Judul cerita : Perlawanan, Summary (Lead), Judul ini menggambarkan tentang perlawan keluarga poligami dalam menghadapi berbagai persolaan, dalam judul ini lebbih bayak menceritakan mengenai kenangan Jusuf Kalla yang mengenang masa kecilnya, tentang bagaimana ketentraman dan keharmonisan keluarga dalam balutan, kecukupan yang luar biasa. Tinggal di tempat yang nyaman, di kampung yang sangat teratur, dalam kehangan keluarga yang sempurna, dengan usaha Bapak dalam berdagang juga sangat laris. Di kalimat lain juga menegaskan bahwa sosok Bapak sangat dihormati oleh banyak orang.

Kalimat dalam bagian isi cerita teks ini memberikan penekanan terhadap bagaimana perasaan seorang anak yang menghadapi masalah keluarga yang cukup serius, berpikir bahwa anak-anak tersebut merasa terluka melihat ibunya terluka karena suatu kejadian Bapak menikah lagi, sehingga anak-anak tersebut memikirkan bagaimana cara untuk melakukan perlawanan pada keputusan yang telah diambil oleh Bapak.

Penekanan pada bagian ini bermaksud bagaimana sikap atau keinginan seorang anak untuk melakukan perlawanan terhadap hal yang tak ia inginkan. Merasakan bagaimana persoalan paling besar dalam anak dari keluarga poligami 
itu adalah kepada siapa harus berpihak, entah berpihak pada ayah atau pada ibu, atau terus berpura-pura dan seolah semuanya baik-baik saja dan tak ada masalah, dan terus bersikap tak peduli.

Keempat, Judul cerita : Ikhlas dan syukur, Summary (Lead). Dalam lead cerita ini menjelaskan tentang sikap Ikhlas dan Syukur dalam menjalani kehidupan. Pada Lead ini lebih menceritakan bagaimana perjuangan Jusuf Kalla anak laki-laki tertua Emma Athirah yang sedang berjuang untuk mendapatkan hatinya Mufidah, dalam cerita ini dapat diambil hikmah apabila kita menghadapi ujian dan cobaan dengan hati yang penuh keikhlasan dan bisa menghadapi semua hal dengan penuh ketabahan. Begitu juga contoh yang dapat diambil Jusuf dari Emma Athirah dalam menyikapi Mufidah, dan bersyukur karena masalah Bapak menikah lagi itu menjadikan Jusuf sosok anak laki-laki tertua yang bertanggung jawab dan mampu menjadi sandaran bagi Emma dan juga saudara-saudaranya.

Di cerita ini penulis menerangkan perjuangan seorang laki-laki yang mencintai wanita yang menghadapinya dengan sikap yang tak suka, lalu beliau tidak pernah menyerah untuk mendapatkan wanita yang istimewa itu, yang terus menerus membuat laki-laki itu dirundung kegelisahan. Wanita yang tak mudah untuk mempercayai laki-laki.

Pada paragrap lain menjelaskan juga bagaimana seorang laki-laki itu tak mau menyerah begitu saja, pengalaman hidup yang terjadi padanya selama ini adalah bentuk dari hikmah dan pembelajaran yang sangat berharga, belajar arti ikhlas dan bersyukur dalam segala hal. Sosok Jusuf Kalla dalam perjuangannya mendapatkan Mufidah sangat dipengaruhi oleh apa yang tejadi pada Emma Athirah dan juga Haji Kalla. Disikapi begitu oleh Mufidah tak membuat Jusuf Kalla marah, ia juga mengerti bahwa laki-laki memang tak boleh sepenuhnya diyakini, dan setiap perempuan berhak bersikap angkuh untuk memutuskan siapa yang berhak mendapatkan cinta dan kepercayaan.

Namun setelah melewati perjuangan, akhirnya Mufidah sedikit demi sedikit perubahan sikap pada Jusuf kalla, tepatnya pada saat di Bantimurung saat sedang diadakannya sebuah wisata sekolah, dan kelas Mufidah yang menyelenggarakan kegiatan tersebut.

Hasil Pada penelitian ini, superstruktur pesan dakwah dalam karya sastra, pada novel Athirah cerita pertama perempuan dari rabim kesabaran, cerita kedua Engkau mengalah, bukan kalah, cerita ketiga perlawanan, dan cerita keempat ikblas dan syukur, secara keseluruhan kerangka suatu teks secara utuh dalam novel ini menggunakan alur yang mudah dimengerti, cerita di dalam teks novel tersebut disajikan dengan alur maju dan ada beberapa alur mundur atau menceritakan kisah lampau (Flashback), namun meskipun demikian makna yang disampaikan pada novel Athirah ini memiliki nilai pesan yang mudah dipahami. 


\section{Struktur Mikro Pesan Dakwah Karya Sastra dalam Novel Athirah}

Pertama, semantik, terdiri dari latar yaitu "Latar merupakan sutau bagian berita yang mempengaruhi semantik (arti) yang ingin ditampilkan seorang wartawan dapat menentukan latar dari berita itu sendiriyang mana kelak latar yang dipilih akan menentukan kemana arah pandangan khalayak akan dibawa" (Eriyanto, 2001:235). Detail yaitu Detail yang terdapat dalam novel ini, masing-masing disetiap judulnya, diceritakan secara panjang lebar karena semua penulis menceritakan detail ini dengan mengungkapkannya dengan sudut pandang atau cara dan bahasa mereka masing-masing. Sedangkan maksud, pada bagian ini peneliti akan mengolompokan dengan cara menunjukan maksud penulis dengan menggunakan tabel sebagai berikut:

Tabel: 2: Analisis Teks Maksud

\begin{tabular}{ll}
\hline Judul & Maksud \\
\hline Perempuan dari & Cerita ini bermaksud menyampaikan kepada \\
rahim kesabaran & pembaca bahwa seorang perempuan yang \\
& terlahir dari kisah yang penuh dengan ujian dan \\
& kisah pilu dan luka yang hampir sama, kini \\
& dirasakan kembali dan mengguncang kehidupan \\
& rumah tangganya, namun dengan perasaan yang \\
& sabar perempuan itu tetap menghormati dan \\
& tetap menciptakan ketentraman yang sama. \\
Engkau mengalah, & Cerita ini memiliki maksud bahwa perasaan \\
bukan kalah & Emma yang sabar dan tabah itu pada satu titik \\
& sampai pada perasaan yang tak percaya diri, \\
& terutama selain ujian dari luar juga ujian dari \\
& dalam rumah yang tak kalah berat, membuat \\
& Emma berpikir bahwa dia elah kalah, namun \\
& anak-anaknya selalu menguatkannya, bahwa \\
& Emma tidak kalah, hanya saja Emma sedang \\
& mengalah \\
& Maksud dari cerita ini adalah ketidak siapan \\
ketidak ikhlasan dan ketidak sangguupan anak- \\
anak beserta Emma dalam menghadapi \\
persoalan poligami, merasa kehilangan Bapak \\
yang telah memiliki keluarga baru, karena sangat \\
menghormati Bapak, dan sikap Emma yang \\
selallu pasrah dan tak memberikan perlawanan,
\end{tabular}


Ikhlas dan syukur

membuat anak-anaknya sangat terluka. Sekalipun sangat menghormati Bapak, mereka juga tak kalah merasa terluka dan merasa marah terhadap keadaan yang terjadi.

Maksud dari cerita ini adalah setelah mengalami perhara yang begitu memberikan banyak luka terutama pada Emma dan juga nak-anaknya, selama melewati tahun-tahun yang sangat menggesek emosi akhirnya sampai lah pada tahun yang menguji pada ketahanan hati, bagaimana segala hal yang terjadi harus diterima dengan ikhlas, dan hal yang terasa menyakiti itu masih harus tetap di syukuri

Sumber: hasil penelitian

Pada tabel 2 ini menjelakan mengenai contoh dari elemen maksud yang merupakan bagian dari semantik. Hal tersebut merupakan contoh-contoh elemen maksu yang terdapat dalam novel Athirah. Adapun yang dimaksud dengan maksud ialah Elemen ini memperlihatkan apakah informasi yang diberikan ekspilisit atau tidak, umumnya jika informasi yang dapat menguntungkan komunikator akan bersifat eksplisit atau jelas akan diuraikan dengan samar dan tersembunyi. Tujuan akhir yang diberikan kepada publik adalah hal yang akan menguntungkan komunikator (Sobur, 2015: 79).

Kedua, Sintaksis adalah salah satu komponen dari struktur mikro, pada tahap ini yang akan diteliti ialah tentang bagaimana kalimat atau pendapat itu disajikan, dalam hal ini strategi yang dipakai yaitu dengan cara mencari, koheren, bentuk kalimat, dan kata ganti, terdiri dari koherensi, bentuk kalimat, dan kata ganti. Koherensi adalah keterkaitan atau jalinan antar kata, ataupun antar kalimat dalam sutau teks, hubung yang digunakan dalam koherensi adalah (dan, akibat, tetapi, lalu, karena, meskipun).

Tabel. 3 koherensi dalam novel Athirah

\begin{tabular}{cc}
\hline Judul & Kalimat yang mengandung koherensi \\
\hline $\begin{array}{c}\text { Perempuan dari rahim } \\
\text { kesabaran }\end{array}$ & ayahku memiliki kantor empat lantai, dan \\
& bisnisnya membuat dirinya mengenal banyak \\
& orangpenting di kota kami \\
& jika bapakp pergi lama, lalu tak pulang \\
Engkau mengalah, & apakah kau takut? \\
bukan kalah & sejak menikah hingga hari itu, ia dikenal \\
& sebagai kuat dan ia ingin terus seperti itu
\end{tabular}


Perlawanan

Ikhlas dan Syukur
- ia lincah, tapi sangat halus, ia selalu terjaga walau terburu

- karena hormat ku pada Bapak, aku sangat sungkan untuk menjadi nyinyir terhadapnya.

- Kadang, jika Ia memiliki uang lebih, dibelinya ayam segar. Lalu dimasaknya ayam itu dengan dua piliban, nasucela dimasak. merah, atau nasupute imasak putih.

- Entablah, aku tak membela salab satu dari mereka, Tidak, tapi akumenyerap hikmah yang sangat luar biasa.

- Kupikir, selama Emma bersabar dan Ikblas kami akan mengikuti sikap yang sama

\section{Sumber: Hasil penelitian}

Pada tabel.3 ini merupakan tabel yang berisi koherensi yang terdapat dalam novel Athirah. Dalam analisis wacana, koherensi adalah perhentian atau jalinan antarakata, proposisi atau kalimat. Koherensi dapat ditampilkan melalui hubungan sebab akibat bisa juga sebagai penjelas (Sobur, 2015: 81). Kata hubung yang dipakai dalam koherensi adalah (dan, akibat, tetapi, lalu, karena, meskipun).

Selanjutnya bagian dari sintaksis yaitu bentuk kalimat adalah melihat dari sisi sintaksis yang berhubungan dengan cara berpikir logis, yaitu prinsip kualitas. Dalam bentuk kalimat ini, biasanya dibedakan dalam tata bahasa. Bentuk kalimat ini bisa dibagi menjadi dua yaitu kalimat aktif dan kalimat pasif.

Kata ganti adalah elemen yang mempunyai kegunaan untuk memanipulasi bahasa dengan menciptakan suatu komunitas imajinatif. Dalam bagian ini akan mengelompokan berdasarkan judul cerita agar lebih mudah untuk difahami.

Tabel. 4 Kata Ganti Dalam Novel Athirah

\begin{tabular}{cl}
\hline Judul & Kalimat yang mengandung kata ganti \\
\hline Perempuan dari rahim & - "aku memiliki dua orang tua yang sempurna, \\
kesabaran & saudara-saudara yang hangat, dan kami adalab \\
& keluarga berkecukupan di Makasar”. Dalam \\
& kalimat ini terdapat kata ganti yaitu kata \\
& kami yang menunjukan kepada orang tua \\
& dan juga saudara-saudara.
\end{tabular}

Engkau mengalah, - "Kemudian, setelah ia mencukupi bukan kalah kebutuhannya untuk. bertemu dan berdialog 
Perlawanan

Ikhlas dan Syukur dengan kami Bapak melesat lagi ke luar rumah". Dalam kalimat ini, terdapat tiga kata ganti kata ia, nya, dan juga kami, kata ia menunjukan pada sosok Bapak, begitupun dengan kata 'nya', lalu kata ganti kami menunjukan pada istri dan anak-anaknya.

- "Ternyata ketenangan di rumah kami pada tahun itu sebetulnya hanyalah bungkus dari peraaan porak poranda yang mati-matian kami kubur". Dalam kalimat ini kata ganti "kami" menunjukan perasaan anak-anak dan istri yang terluka

- Tapi lama-kemaaan mereka berhenti menertawaiku". Dalam kalimat ini terdapat kata ganti mereka menunjukan pada kawan-kawan Jusuf, yaitu Anwar, Abdullah, dan Abduh

Sumber: Hasil penelitian

Pada tabel.4 ini menjelaskan penggunaan kata ganti oleh penulis dalam novel Athirah. Kata ganti adalah yang mana elemen ini bertujuan untuk memanipulasi bahasa dengan menciptakan suatu komunitas imajinatif kata ganti merupakan bahahasa yang digunakan oleh komunikator untuk menunjukan posisi seseorang dalam wacana contohnya seperti aku, kita, kami, ayah bunda dan lain sebagainya (Eriyanto, 2001: 235)

Ketiga, leksikon pada bagian ini pada dasarnya ingin menunjukan bagiamana seorang melakukan pemilihan kata atas berbagai alasan, kata yang tersedia untuk menja suatu komponen dalam tulisannya.

Keempat, Retoris, dalam tahapan ini adalah mencari gaya yang ditunjukan seorang pembicara atau penulis dengan menggunakan cara yaituterdiri oleh Grafis yang ditemukan dalam novel Athirah dalam kalimat sebagai berikut.

"ibumu labir dari rabim kesabaran", tutur seorang tetua dulu saat aku masih berusia dibawah sepulub tabun. "Ia barangkali telab menangis dalam kandungan". Kalimat ini termasuk pada grafis yang ada pada cerita perempuan dari rahim kesabaran halaman 30, kalimat ini ingin menunjukan bahwa cerita ini menonjulkan bahwa pemeran utamanya yaitu sosok perempuan yang begitu sabar. Selanjutnya yaitu Metafora, Metafora adalah bagian yang ingin 
memberikan pesan pokoknya tidak hanya melalui teks saja tetapi juga bbisa mamakai kiasan. Metafora dalam nnovel Athirah seperti berikut:

"Tahun saat bayanganku akan kehidupan kemudian pecah berantakan seiring dengan realitas tak terduga menghampiri kami, tahun yang memaksaku untuk belajar menyusun remab-remah kenyataan pabit menjadi sebuah kenyataan baru: berdiri diatas perasaan sakit" klimat ini terdapat pada cerita perempuan dari rahim kesabaran terdapat pada halaman 17

Hasil penelitian dalam struktur mikro pesan dakwah dalam karya sastra, pada novel Athirah pada bab judul perempuan dari rabim kesabaran, Engkau mengalah, bukan kalah, perlawanan, ikhlas dan syukur, secara keseluruhan dengan menggunakan beberapa elemen yang diteliti yaitu segi semantik, skematik, stilikis, dan retoris suatu teks yakni pada bab judul cerita di novel ini menggunakan kata sambung, kata ganti dan gaya bahasa penulis yang menarik dan membuat cerita ini tak mudah bosan ketika dibaca. Penulis juga menggunakan bahasa yang cukup luas, menggunakan banyak kata ganti dan beberapa ada yang menggunakan bahas kiasan atau perumpamaan, lalu bentuk kalimat yang digunakan kebanyakan menggunakan bentuk kalimat aktif.

\section{PENUTUP}

Berdasarkan dari penelitian dalam analisis yang telah dilakukan penulis dalam teks naskah novel Athirah karya Alberthiene Endah, maka peneliti menyimpulkan bahwa wacana pesan dakwah yang terdapat pada novel Athirah ini terdiri atas pesan aqidah, akhlak serta ibadah. Namun pesan yang relatif mendominasi dalam novel Athirah ini ialah pesan Akhlak. Hal tersebut dapat dilihat setelah melakukan analisis terhadap novel Athirah dengan menggunakan pendekatan teori analisis wacana Teun A Van Dijk.

Dari hasil pemaparan yang telah disampaikan, maka dapat ditarik kesimpulan sebagai berikut: pertama Struktur makro novel ini dikemas oleh penulis dengan menggunakan tema dakwah yakni kesabaran sosok seorang perempuan, yakni seorang ibu dan juga istri dalam menerima persoalan poligami. Selain itu novel ini juga menceritakan bagaimana tangguh kuat dan sabarnya ibu dan juga anak-anaknya ketika mengetahui jika sosok ayahnya telah memiliki keluarga baru. Kedua, superstruktur penulis dalam menulis novel ini menggunakan alur maju mundur atau flashback menceritakan masa lampau, dan cukup mudah dimengerti dalam setiap penekanan dalam struktur teks dan memiliki nilai pesan yang mudah difahami. Ketiga, Struktur mikro pada novel ini banyak menggunakan kata sambung, kata ganti, dan gaya bahasa penulis yang memiliki tujuan untuk memberikan pesan dan kesan yang nyaman dan membuat cerita ini tidak bosan. 
Adapun dalam penelitian ini, ada beberapa saran yang telah peneliti sampaikan diantaranya yaitu: Pertama, Bagi penulis novel Athirah ini diharapkan bisa terus membuat karya-karya sastra yang lainnya, terutama karya sastra novel tentunya peneliti berharap bahwa didalamnya akan mengandung pesan dakwah yang bisa diterapkan pada kehidupan masa kini, agar pembaca zaman sekarang yang lebih menyukai membaca novel bisa tetap menerima proses dakwah dan pesan dakwah dalam tulisan tersebut. Kedua, Bagi semua para pembaca yang ingin mencari novel yang bermuatan dakwah Islam, bisa membaca novel Athirah karya Alberthiene Endah. Karena selain menceritakan tentang kehidupan dari sosok penting di negara ini yaitu Jusuf Kalla. Novel ini relatif banyak memberikan pesan dakwah, khususnya bagi kaum perempuan dalam belajar arti kesabaran dan ketangguhan sosok ibu sekaligus sosok istri yang baik dan penuh nilai-nilai pesan dakwah.

Selanjutnya Ketiga, Bagi peneliti diharapkan untuk kedepannya akan semakin banyak yang melakukan penelitian tentang pesan dakwah dalam karya sastra, karena melakukan penelitian dalam ranah tulisan sastra juga merupakan hal yang penting dan tak bisa dianggap enteng. Dan bagi peneliti yang selanjutnya diharapkan bisa mencari lebih banyak lagi pesan dakwah yang terkandung di dalam sebagian judul cerita lain pada novel Athirah ini, yang peneliti anggap memiliki pesan dakwah yang masih harus dikaji lebih mendalam pada pesan lainnya, karena pesan dakwah dalam novel ini masih banyak yang bisa diteliti dan dikaji dengan bahasan yang lebih baik dari hasil penelitian ini. Keempat, Bagi pemerintah diharapkan untuk kedepannya semakin banyaknya novel-novel yang terdapat pesan dakwah di perpustakaan-perpustakaan agar bisa mempermudah untuk para pemabaca dalam membaca novel yang memiliki pesan dakwah.

\section{DAFTAR PUSTAKA}

Aripudin A, (2011), Pengembangan metode dakwah, Jakarta: Raja Grafindo persada Amin S M, (2009) Ilmu Dakwah, Jakarta : Amzah Ed. 1, Cet.1

As Enjang, \& Aliyudin.(2009). Dasar-dasar ilmu Dakwah. Bandung : Widya

Padjajaran.

Eriyanto, (2001) analisis wacana: pengantar analisis teks media, Yogyakarta: PT Lkis pelangi aksara Yogyakarta

Hajir Tajiri, 2015, Etika dan Estetika Dakwah, Bandung: Remaja Rosdakarya

Ilahi W, (2010), Komunikasi Dakwah. Bandung: Remaja Rosdakarya

Indrawati, (2013) mengapresiasi novel sebagai media dakwah bil-qalam,

Dalam Jurnal Dakwah dan kemasyarakatan, 14: 2, 217-226

Kusnawan Aep, (2016) . Teknik menulis Dakwah Bandung: Simbiosa Rekatama Media 
N. Herlina, D. E. S. Amin \& R. Aziz

Munir M, \& ilahi Wahyu, (2009), manajemen dakwah, Jakarta: prenada media Group.

Nurgiantoro B, (2000). Teori pengkajian fiksi .Yogyakarta: Gajahmada University press.

Nurujaman H, Restu U, \& Kusuma, B.T (2018) kontruksi Islam sebagai simbol identitas melaluiu reperentasi perempuan Muslim pada Novel religi dalam Ilmu Dakwah: Academic Journal for Homeletic studies 12:1, 61-81

Ramdani L, Sumijati S, Nuraeni, H. G (2018) Pesan dakwah dalam buku humor karya Mustofa Bisri dalam Tabligh jurnal komunikasi dan penyiaran Islam 3:1, 46-67

Saerozi, (2013), ilmu dakwah, yogyakarta: Penerbit ombak

Sambas S, rahmawaty I. S, Dewi. R, (2019) Dakwah Islam Multikultural pada Komunitas sunda, arab alawi dan arab irsyadi dalam Anida: Aktualisasi Nuansa Ilmu Dakwah, 19:1, 83-98

Sobur A. (2009). Analisis teks media. Bandung: Remaja Rosdakarya

Sugono D, (2003), Buku Praktis Bahasa Indonesia, Jakarta: Pusat Bahasa Departemen Pendidikan Nasional

Sukayat T, (2015), Ilmu Dakwah, Bandung: Simbiosa Rekatama Media

Tasmara T, (1997). Komunikasi Dakwah, Jakarta: Gaya Media Pratama

Qadratillah M T ddk, (2011). Kamus bahasa Indonesia untuk

pelajar Jakarta: badan pengembangan dan pembinaan bahasa 